\title{
Persistence in Engineering Education: Experiences of First Year Students at a Historically Black University
}

\author{
Lorraine Fleming, Kimarie Engerman, Ashley Griffin \\ Howard University
}

\section{Introduction}

Most students are motivated and academically prepared to study engineering when they enroll as first year students in engineering majors. Unfortunately, these programs experience considerable attrition between the first two years of study. The literature highlights social and institutional adjustments as well as lost motivation as hurdles that lead to first year attrition. Yet, many students overcome these hurdles and persist to earn engineering degrees. Because first year experiences play a major role in reinforcing persistence for achievement in engineering, it is important for engineering educators to be aware of potential hurdles that can affect student achievement.

Researchers who have studied the factors impacting student persistence have either used a qualitative or a quantitative approach to gathering data. But few, if any, have conducted studies using a mixed method of both quantitative and qualitative procedures together. This paper describes the findings of a mixed method study in which the first year experiences of students of color majoring in engineering are explored. The study focuses on two fundamental questions: (1) What are students' motivations for studying engineering; and (2) Are students satisfied with the institutional factors that are necessary for persistence in engineering? Using grounded theory, persistence factors have emerged inductively from the body of qualitative data (i.e. unstructured ethnographic interviews). The six persistence factors that surfaced were: (1) family influences; (2) financial motivation; (3) mathematics and science proficiency; (4) academic advising; (5) quality of instruction; and (6) availability of faculty. The findings of other researchers pertaining to these factors and their impact on students of color are highlighted below.

\section{Family Influences}

Pearson and Bieschke ${ }^{1}$ found that family relationships influenced career development. Earlier works by $\mathrm{Ogbu}^{2}$ and Leslie, McClure, and Oaxaca ${ }^{3}$ had considered the impact of family influences on minorities. Ogbu stated that African Americans learn the level of optimism they should have about career choice from the family. Leslie et. al.'s study looked at engineering minorities. Their results showed that having a parent in an engineering occupation increased minorities' probability of selecting engineering as a major. Not only did having a parent as an engineer create the perception that becoming an engineer is a realistic goal, but it also reinforced science self-efficacy and supported the student becoming committed to the goal of becoming an engineer.

\section{Financial Motivation}

Studies have shown that in some cases money is a motivational factor for one's choice of careers but in other cases it is not. Heyman, Martyna, and Bhatia's ${ }^{4}$ quantitative study examined the 
impact of potential earning power and prestige on both engineering and non-engineering majors. Women engineering students, unlike their non-engineering counterparts, reported that money and prestige were of great importance in their career choices. However, Grandy's ${ }^{5}$ quantitative study on the persistence in engineering of high-ability minority students found that financial security was not related to persistence in engineering.

\section{Mathematics and Science Proficiency}

Many researchers have studied the relationship between proficiency in mathematics and science and persistence in engineering. Of particular interest, however, are those studies that have focused on understanding the issue as it relates particularly to students of color. Leslie et al. ${ }^{3}$ found that minorities had a lower self-efficacy in mathematics and science in comparison to whites. This quantitative study showed that a higher percentage of whites perceived their mathematics preparation to be better than most others. In the same year, Grandy found that the enjoyment of science and engineering as a major field of study and commitment to science and engineering as a career served as factors leading to persistence in science and engineering for minority students. Similarly, Bonous-Hammarth ${ }^{6}$ reported that retention in science, mathematics, and engineering was positively associated with interest in majoring in science, mathematics, and engineering, and high academic achievement prior to college as represented by strong high school grade point average and SAT-Mathematics scores. Seymour and Hewitt ${ }^{7}$ in their qualitative study found the corollary to be true. They found that the lack or loss of interest in science was a reason why students switched from engineering to another major.

\section{Academic Advising}

Studies by Tinto $^{8}$ and $\mathrm{Lau}^{9}$ have examined the critical role of the student's college experience, particularly in the form of academic advising, on student's persistence in their college careers. Tinto noted that students' persistence is dependent on their college experiences and that students are most successful when they are satisfied with the formal and informal social and academic systems in the institution. Lau further emphasized this point and found that persistence could be improved through academic support in the form of academic advising that students receive.

\section{Quality of Instruction}

A number of studies have shown that the quality of instruction is critical for students to develop the abilities and motivations necessary to succeed in their field of study. Seymour and Hewitt ${ }^{7}$ in their study of science, mathematics and engineering students found that poor teaching by faculty and students feeling overwhelmed by the pace and load of curriculum demands were reasons for students not persisting in engineering. Eimers ${ }^{10}$, who studied both minority and non-minority students, found that satisfaction with the quality of academic program led to progress in college.

\section{Availability of Faculty}

Students who interact frequently with faculty were found to be more satisfied with the college experience $^{11,12}$. Fleming and Morning ${ }^{13}$ found that the lack of nurturing faculty and low teacher contact contributed to the academic difficulty experienced by minority students with high academic records. Additionally, Eimers ${ }^{10}$ results indicated that satisfaction with faculty-student contact led to progress in college for both minority and non-minority students.

\footnotetext{
"Proceedings of the 2005 American Society for Engineering Education Annual Conference \& Exposition Copyright (C) 2005, American Society for Engineering Education"
} 


\section{Methodology}

This study is part of the first phase of an in-depth longitudinal study of engineering students at four institutions-Howard University, Colorado School of Mines, Stanford University, and the University of Washington. The main goal is to gain significant insight into the learning of engineering across diverse student populations and environments with emphasis on the challenges students face and how they handle those challenges. This study will follow students for their first three years of engineering study. This paper focuses on the first year experiences of the thirty-six Howard University students who are participating in the study.

Howard University is one of the leaders in the production of Black engineers. Since its founding in 1867, Howard University's mission has been to provide an educational experience of exceptional quality to students of high academic potential with particular emphasis upon the provision of educational opportunities to promising Black students. Over its 137-year history, Howard University has awarded more than 88,000 Bachelor of Science degrees with more than 10 percent given in engineering and science fields. Howard is honored to be designated Doctoral/Research University-Extensive by The Carnegie Foundation.

The thirty-six (36) student participants were representative of the population of Howard's College of Engineering, Architecture and Computer Science. All six engineering majors were represented with the largest percentage (22\%) of students coming from each of the larger departments (electrical engineering, mechanical engineering and systems \& computer science). The remaining 34\% of the participants were enrolled in computer engineering, chemical engineering and civil engineering. The study participants were one-third female as is the College's population.

The quantitative and qualitative data were gathered from surveys, structured interviews, and ethnographic interviews during the second semester of the participant's first year. The survey was administered to all participants. Descriptive statistics were computed on survey data. The 36 participants were randomly divided into two separate interview groups. Twenty-eight participants took part in structured interviews where the interviewer asked specific predetermined questions. The remaining eight students participated in unstructured ethnographic interviews in which the interviewers used prompts to stimulate the discussion. Follow up questions were asked on topics and issues that were introduced by the student.

\section{Results}

Questions from the survey and direct quotes from both the structured and the ethnographic interviews were sought to support or refute the persistence factors that originally emerged from the ethnographic interviews. The results are described below.

\section{Survey Results}

The survey provided quantitative results on the two fundamental research questions and the six persistence factors being examined. These results are summarized in Table 1 below. Note that seventy-five percent of respondents indicated that the enjoyment of mathematics and science and financial concerns were motivational factors in their pursuit of an engineering education. Family influence is noted as a less significant factor. The table also shows that only a small number of 
students indicated satisfaction with their academic advising but almost twice as many were satisfied with the quality of instruction and the availability of faculty.

Table 1. Survey Results

\begin{tabular}{|c|c|c|c|}
\hline \multicolumn{4}{|c|}{ Research Question 1: What are students' motivations for studying engineering? } \\
\hline & $\begin{array}{l}\text { SURVEY QUESTIONS } \\
\text { Do you agree that ... }\end{array}$ & $\begin{array}{l}\text { Percent in } \\
\text { agreement }\end{array}$ & PERSISTENCE FACTORS \\
\hline & $\begin{array}{l}\text { Your reason for studying engineering is } \\
\text { because parents want you to become an } \\
\text { engineer. }\end{array}$ & 16.7 & Family Influences \\
\hline & $\begin{array}{l}\text { Your reason for studying engineering is } \\
\text { because engineers are well paid. }\end{array}$ & 75.0 & Financial Motivation \\
\hline & $\begin{array}{l}\text { Your reason for studying engineering is } \\
\text { because you enjoy science and mathematics. }\end{array}$ & 75.0 & Math and Science Proficiency \\
\hline \multicolumn{4}{|c|}{$\begin{array}{r}\text { Research Question 2: Are students satisfied with the institutional factors that are } \\
\text { necessary for persistence in engineering? }\end{array}$} \\
\hline & \multicolumn{2}{|c|}{$\begin{array}{c}\text { SURVEY QUESTIONS } \\
\text { Indicate the [persistence] factors with which you are satisfied }\end{array}$} & Percent satisfied \\
\hline & \multicolumn{2}{|l|}{ Academic Advising } & 38.9 \\
\hline & \multicolumn{2}{|l|}{ Quality of Instruction } & 66.7 \\
\hline & \multicolumn{2}{|l|}{ Availability of faculty } & 72.2 \\
\hline
\end{tabular}

\section{Structured and Ethnographic Interviews Results}

The qualitative data from the structured and ethnographic interviews provided insight into the survey results. The interview provided additional detail and information in guiding the study. The following are brief representative excerpts from both the ethnographic interviews and structured interviews compiled according to the six persistence factors being examined. Pseudonyms are used in reporting the data.

\section{Family Influences}

Although most students did not identify family influences as a persistence factor in the survey, those who did had strong feelings about the influence of family. Karen, a female, mechanical engineering major discussed the role her father played in her decision to study engineering. She states "...My dad is an engineer. I liked watching him go to work. He's a mechanical engineer. That's the same thing I'm studying. Yes he did [influence my decision to study engineering] and it wasn't forced or anything. I just, I just really liked what I saw." (ethnographic interview). Similarly when Jordan, a male, systems and computer science major was asked how the experiences of family members or close acquaintances influenced his decision to become an engineer, he stated, "I would find [my father's work] quite interesting and intriguing." (structured interview)

\section{Financial Motivation}

The survey finding that large numbers of students are motivated by money to persist in engineering is supported by comments made by students in the both types of interviews. For some students, like Wynette, a female, electrical engineering major, money was the only reason to study engineering. She said, "Honestly, the only thing that made me want to be an engineer is the money. Yes, honestly. The money's the driving force." (ethnographic interview). When asked why being an engineering student was important to how she felt about herself, Denise, a female, 
systems and computer science major stated that, "I feel secured that after I finish my school, I'm more likely going to get [a job].” (structured interview)

\section{Mathematics and Science Proficiency}

Most students surveyed indicated that they enjoyed mathematics and science but there were a number who did not. Terrell, a male mechanical engineering major has enjoyed mathematics since high school. He stated, "I really enjoyed math. I mean I did math problems for the fun of it. When I was bored at home, I would do math problems." (ethnographic interview). Similarly, when David, a male, civil engineering major, asked if there are any aspects of engineering that he particularly liked, stated, "I like the science part because it helps us learn new things about the project we're working on." (structured interview). On the other hand, Laurie, a female systems and computer science major, does not enjoy math. She stated, "I don't like math and science because it's not coming as easy as stuff like history ... I think [making an A on a math quiz is] so much more fulfilling. I don't like the challenge of [math], but ... I know that the math is rewarding." (ethnographic interview)

\section{Academic Advising}

Student's dissatisfaction with academic advising was clearly evident in the survey results and supported by comments made during the interviews. For example, Greg, a male, mechanical engineering student stated "My advisor . . really, really sucks . . . every time I try to talk to [him] [he] acts like [he] is trying to rush me out the office.... [H] 's never available, it takes [him] a week to email me back, and every time... I scheduled something to do with [him] ... [he] missed ... [the] appointment. And you just talk to [him], you know, you could tell how people really feel about you, and [he] doesn't look like [he] cares ..." (ethnographic interview). When Emile, a male, civil engineering major was asked if there were any aspects of being an engineering major at this institution that he found particularly difficult in achieving his academic goals, he stated, "[M]y advisor made it difficult last semester because uhm [sic] I would tell him about taking certain courses and he was supposed to tell me certain things but I didn't know those things and he caused problems for me with the civil engineering department." (structured interview)

\section{Quality of Instruction}

Although most students were satisfied with the quality of instruction, both the satisfied and unsatisfied students had strong opinions. Mary, a female, electrical engineering student discussed one of her professor's effects on her achievement. Mary stated, "I have Professor [A] and he is a genius. I'm serious. He is too good at ... what he does. He just makes you think you're going to get it. ... It's so obvious to him. So when he goes on the board and work, and you can't help but just follow him, and he just makes it so easy... It's motivating and I just do it and I get it done and you can reap some benefits, you can see effects of it." (ethnographic interview) However, Wynnette, a female, electrical engineering major expressed dissatisfaction with the quality of instruction she received. Wynette stated, "[Y]ou just come in the class [and professors] expect you to know what they're talking about automatically. They'll just start writing on the board, and me, personally, I don't learn by reading a book at night. I need somebody to show me step by step how to do a problem, and they don't do that ... It has drastically affected my math grades and it's making me not want to pursue a career in 
engineering anymore, being that I'm gonna [sic] have to take all these math classes and so far, the teachers that I've experienced, they don't know how to teach." (ethnographic interview) When asked if there are any aspects of being an engineering major at this institution that he found particularly helpful in achieving his academic goals, Marcus, a male, chemical engineering major indicated his satisfaction, "My calculus professor . . goes into more detail because he knows we can understand it ..." (structured interview)

\section{Availability of Faculty}

During the interviews students expressed satisfaction with the availability of faculty. Laurie, a female, systems and computer science major met with her mathematics professor when she was having difficulty in his class. Laurie stated, "I don't go [to] tutoring anymore, I used to go to tutoring, but um [sic] my math teacher suggested that I just sit down and think about the problem instead of being so quick to run to somebody for help. And that's helped [me] improve." (ethnographic interview) Similarly, when Joseph, a male, computer engineering major was asked if there are any aspects of being an engineering major at this institution that he found particularly helpful in achieving his academic goals, stated, "[T]he access to professors that we have here is really helpful." (structured interview)

\section{Summary}

Unlike prior studies this work has focused on a pool of students of color at a historically Black institution. These students are diverse in their academic ability and socio economic backgrounds. Many are the first in their families to attend college. Focusing on students of color with these diverse characteristics allows the findings to be generalized to other settings with similar demographics including students of color at Predominantly White Institutions.

The results of this study provide an insight into the factors that affect the persistence of students of color in engineering at an HBCU. The initial findings suggest that many of the persistence factors found in studies of other populations are also potential factors for students of color. One factor, financial motivation, appears to be a strong factor in persistence although other researchers ${ }^{5}$ did not find it to be significant. This difference is to be expected since Grandy's ${ }^{5}$ study focused on high-ability minority students who may not have come from the diverse socioeconomic background of the students in this study.

Surveys and interviews will be used over the next two years to continue to gather data on the study participants. Ultimately, however the richest data will be obtained when it is known which students persist to earn engineering degrees and the hurdles they overcame.

\section{Acknowledgements}

This material is based on work supported by the National Science Foundation under Grant No. ESI-0227558, which funds the Center for the Advancement of Engineering Education (CAEE). We would also like to acknowledge the contributions of the other researchers collaborating in the CAEE APS study, specifically Tori Bailey, Helen Chen, Angela Cole, Ozgur Eris, Lari Garrison, Kevin O'Connor, Sheri Sheppard, and Reed Stevens for their valuable contributions to this research.

\footnotetext{
"Proceedings of the 2005 American Society for Engineering Education Annual Conference \& Exposition Copyright (C) 2005, American Society for Engineering Education"
} 


\section{References}

1. Pearson, S.M., \& Bieschke, K.J. (2001). Succeeding against the odds: An examination of familial influences on the career development of professional African American women. Journal of Counseling Psychology, 48(3), 301-309.

2. Ogbu, J. U. (1988). Black education: A cultural-ecological perspective. In H. P. McAdoo (Ed.), Black Families. Thousand Oaks, CA: Sage.

3. Leslie, L.L., McClure, G.T., \& Oaxaca, R.L. (1998). Women and minorities in science and engineering: A life sequence analysis. The Journal of Higher Education, 69(3), 239-276.

4. Heyman, G.D., Martyna, B., \& Bhatia, S. (2002). Gender and achievement-related beliefs among engineering students. Journal of Women and Minorities in Science and Engineering, 8. 41-52.

5. Grandy, J. (1998). Persistence in science of high-ability minority students: Results of a longitudinal study. The Journal of Higher Education, 69(6), 589-620

6. Bonous-Hammarth, M. (2000). Pathways to success: Affirming opportunities for science, mathematics, and engineering majors. The Journal of Negro Education, 69(1/2), 92-111.

7. Seymour, E., \& Hewitt, N. (1997). Talking about leaving: Why undergraduates leave the sciences. Boulder, Colorado: Westview Press.

8. Tinto, V. (1987). Leaving college: Rethinking the causes and cures of student attrition. Chicago: University of Chicago Press

9. Lau, L. (2003). Institutional factors affecting student retention. Education, 124(1), 126-136.

10. Eimers, M.T. (2001). The impact of student experiences on progress in college: An examination of minority and nonminority differences. NASPA Journal, 38(3), 386-409.

11. Astin, A. (1985). Achieving educational excellence. San Francisco: Jossey-Bass.

12. Kramer, G.L., \& Spencer, R.W. (1989). Academic advising. In M. L. Upcraft, J.N. Gardner, and Associates, The freshmen year experience: Helping students survive in college (p. 95-107). San Francisco: Jossey-Bass.

13. Fleming, J., \& Morning, C. (1998). Correlates of the SAT in minority engineering students: An exploratory study. The Journal of Higher Education, 69, 89-108.

"Proceedings of the 2005 American Society for Engineering Education Annual Conference \& Exposition Copyright $\odot$ 2005, American Society for Engineering Education” 